\title{
Dancing Around the Same Spot? Land Reform and NGOs in Zimbabwe - The Case of SOS Children's Villages
}

\author{
K D Helliker \\ Department of Sociology, Rhodes University \\ Grahamstown. \\ k.helliker@ru.ac.za
}

\begin{abstract}
This paper discusses the rural-based operations of an international NGO in Mashonaland Central province, Zimbabwe. The aim is to highlight the contingent variation of NGO practices within defined limits. It does this through 'thick description' of the NGO of focus, the SOS Children's Village, and compares its 'handling' of the transforming countryside with the response of two other NGOs. It concludes by suggesting some conceptual points in understanding organizational dispositions of NGOs.
\end{abstract}

Keywords: NGOs, organizational stability, Zimbabwe, land reform, agrarian change, SOS Children's Village

\section{Introduction}

Non-governmental organisations (NGOs) in the Global South exist in a social field that is marked by significant tensions, in large part because this field embodies contradictions between global and local processes. NGOs regularly seek to handle or 'manage' these countervailing pressures in a manner that simplifies and gives order to their world of ambivalence. Despite their lofty missions about changing an unjust social order, NGOs often avoid complexity and follow the route of least resistance. They seem more concerned about sustaining themselves as viable organisational formations than about forging ahead with sustainable development in marginalised or disadvantaged communities. Particularly at times of intense political conflict at the national level, NGOs aim to maintain organisational coherence or to 'weather the storm' so to speak. This occurs for example in situations involving dramatic struggles around land, such as in contemporary Zimbabwe under 'fast track' land reform (Moyo, Helliker and Murisa eds, 2008). 
Handling tensions to bring about organisational stability is however merely a trajectory, albeit a dominant one for NGOs. Contrary tendencies also exist. Indeed, there is considerable temporal and spatial variation in how NGOs manoeuvre their way through their tension-riddled world, including with regard to land reform (Ghimire ed, 2001; Kanji, Braga and Mitullah, 2002). Systemic 'structures' and contingent 'struggles' merely set limits to (or condition) NGO practices; within these parameters, there is considerable scope for alternative social projects. For instance, at times of embittered social struggles over land, some NGOs 'constructively engage' with the heightening tensions and 'use' these tensions in a creative way to animate and adapt the organisation to the shifting political terrain. Other NGOs are far more circumspect, either 'feeling the water' (i.e. acting cautiously) or preferring to avoid or sidestep the deepening tensions altogether in a 'business as usual' approach. This diversity suggests that NGOs do not necessarily dance around the same spot.

In the context of the 'fast track' land movement in contemporary Zimbabwe, this paper discusses the rural-based operations of an international NGO (SOS Children's Villages) in Mashonaland Central province from the late 1990s until the year 2006. I offer a 'thick description' of key processes internal to the organisation as the turbulent events of 'fast track' swirled around it. This particular NGO made no attempt to alter its operations to fit the transforming countryside; rather, it simply responded to crises on an $a d$ boc, unstructured and informal basis. The rising tensions were not 'handled' by the organisation yet the tensions became embedded in the life of the organisation. This became disabling for the NGO's rural programme, and the organisation seemed to be moving in the direction of an implosion. The process was further complicated by the historical legacy of a hierarchical structure that was firmly racially- and gender-based (controlled by White males).

The major part of the paper entails a 'thick description' of this NGO's 'hand-offs' (and potentially destructive) approach to 'fast track'. I then briefly compare the stance of this NGO to the (more proactive) responses of two other NGOs operating in the same province (and indeed same district) of Zimbabwe. The comparison highlights the contingent variation of NGO practices within defined limits. The paper concludes by offering some conceptual points that hopefully assist in understanding the organisational dispositions of NGOs.

Before presenting the 'thick description' of the NGO, I first provide necessary context. I reflect briefly on some general theoretical points relevant to making sense of NGOs, and I then describe the contemporary politics of 'fast track' land reform in Zimbabwe.

\section{Intermediary NGOs - Theoretical Reflections}

The term 'NGO' is an inherently negative, residual and nebulous term that at times 
seems to distract rather than contribute to meaningful theoretical debate. Definitions, taxonomies and typologies abound within the almost infinite literature on NGOs (Uphoff, 1996; Vakil, 1997). Often, sweeping claims are made about the character and role of NGOs, so it is necessary to demarcate the specific focus of this paper. In his seminal study of rural NGOs in Latin America, Carroll (1992) distinguishes between grassroots organisations (for example, local peasant bodies) and (non-membership) grassroots support or intermediary NGOs that forge links 'between the beneficiaries [of their work] and the often remote levels of government, donor, and financial institutions' (Carroll, 1992:11). This metaphorical use of 'levels' highlights an important point about 'intermediary' NGOs, namely, their in-between social field or location. Intermediary NGOs have been provocatively labelled as 'problematic organisations' in that they 'must live and work in situations of necessary ambiguity' (Edwards and Hulme, 1996:260). As a specific kind of social form with particular organisational histories and trajectories, they occupy an ambiguous - and constantly negotiated and reconfigured - social space and are structurally located in a complicated 'web' of social relations as part victim and part maker.

Intermediary NGOs are deeply embedded in contradictory processes of globalisation and are implicated in them. But whether in practice they act as 'intermediaries' (rather than say as 'agents', 'representatives' or even 'instruments' of others) is a contingent question requiring thorough historical investigation. In fact, part of the 'finely-balanced ambivalence' of intermediary NGOs, to borrow a phrase from Morris-Suzuki (2000:84), is this tension - never resolved but rather managed in different ways - between their work as agents and their work as intermediaries. The tensions that riddle the world of intermediary NGOs play themselves out in organisational practices that are historically specific and variable.

There is considerable diversity within the intermediary NGO 'sector' in terms of political and ideological dispositions. Nevertheless, I would suggest that - generally speaking - intermediary NGOs valorise global processes of a capitalist modernising kind. These globalising processes at times enact closure, albeit unsuccessfully, on more localised and potentially empowering organisational and political initiatives. This general trajectory of NGO practices is not structurally foreordained but is the outcome of indeterminate social processes.

This theorisation of NGOs is an alternative to functionalist analyses in which NGOs exist (for instance) in order to provide conditions for the reproduction of global capital. It also goes beyond instrumentalist claims in which NGOs are mere agents of capitalism working at the behest of (or even on behalf of) capitalist organisations as part of a coordinated and cohesive 'conscious conspiracy' (Manji and O'Coill, 2002:579). NGOs in this regard are said to have 'a hidden agenda' (Monga, 1996:156) or at least to be part of a global 'hidden hand'. As Crewe and Harrison (1998:89) note: 'Donors [and their NGO "creations"] are sometimes portrayed as strategically wielding the control 
they have over recipients for their own ends in a coordinated way to uphold the present capitalist system'. Yet, as suggested below, the NGO story may still be a 'straightforward' one based on the common view, as often propounded by development practitioners themselves, that the sheer 'institutional survival [of NGOs] depends upon the status quo' (Eade, 2003:xi).

\section{Fast track' in Zimbabwe}

'Fast track' (and the land occupations that formed a central part of it) derived from a complicated mix of three tendencies. First of all, there was the historical legacy in Zimbabwe of racially based landed property that remained unresolved twenty years after independence. Secondly, global agricultural restructuring and policy failures by the Zimbabwean state impacted on rural livelihoods and the desperate struggle for social reproduction. Thirdly, a radical pan-African nationalism arose as a result of imperialist aggression, disinterest and withdrawal vis-à-vis Zimbabwe (Bernstein, 2005). Of course, these conditions neither made the 'fast track' land movement inevitable nor determined its historical specificities. But they do show that both global trajectories and local conjunctural events were significant in the emergence of the Third Chimurenga ${ }^{1}$.

The land occupation movement in present-day Zimbabwe, it is argued, is 'the most notable of rural movements in the world today'; it has been 'the most important challenge to the neocolonial state in Africa' under neo-liberalism; and - controversially in the eyes of many 'fast track' critics - there are grounds for arguing that it has a 'fundamentally progressive nature' (Moyo and Yeros, 2005:165, 188). This depiction of the Third Chimurenga, most notably the reference to the progressive nature of 'fast track', has been the subject of an important but acrimonious debate amongst Zimbabwean Left scholars about state formation and political change (e.g. Moyo, 2001; Yeros, 2002; Raftopoulos and Phimister, 2004; Moore, 2004; Raftopoulos, 2005; Helliker, 2005).

The many critics of this depiction claim that it entails - almost perverse - value judgments made by 'patriotic agrarianists' (Moore, 2004:409) or 'left-nationalists' (Bond and Manyanya, 2003:78) who fail to conceptualise analytically or even highlight empirically the increasingly repressive character of state nationalism in contemporary Zimbabwe, designated as an 'exclusionary' nationalism (Hammar, Raftopoulos and Jenson eds, 2003), an 'exhausted' nationalism (Bond and Manyanya, 2003) or an 'authoritarian populist anti-imperialism' (Moore, 2003:8). Raftopoulos and Phimister $(2004: 356,376,377)$ argue that this authoritarianism involves an 'internal reconfiguration of Zimbabwean state politics' and now amounts to 'domestic tyranny', and they speak about a 'number of African intellectuals on the Left' who have 'leapt to the defence of ZANU PF' and its re-distributive economic policies.

Regrettably, by way of this debate, 'fast track' is often portrayed in strictly dichotomous 
terms. In this sense, existing analyses of 'fast track' land reform are one-sided and fail to do justice to the full complexities of the process. Such dualism means that the opposing moments embedded in 'fast track' are torn asunder through analytical abstractions that do violence to the contradictory and tension-riddled totality that constitutes 'fast track'. This dichotomous conceptualisation is evident with regard to various issues.

First of all, the controversy is said to involve 'competing narratives of Zimbabwe's national liberation history' (Hammar and Raftopoulos, 2003:17) such that, currently, 'history is at the centre of politics in Zimbabwe' (Ranger, 2004:234). Secondly, the debate supposedly entails fundamentally different conceptions of the current crisis in Zimbabwe. On the one hand, a nationalist discourse speaks of a land crisis and stresses national sovereignty and re-distributive policies. In critically appraising this discourse, Raftopoulos (2005:9-10) says that land 'became the sole central signifier of national redress, constructed through a series of discursive exclusions'. On the other hand, a more liberal discourse refers to a governance crisis and emphasises human rights and political democratisation (Hammar, Raftopoulos and Jensen eds, 2003; Sachikonye, 2002).

Thirdly, the determinants of the crisis are painted as diametrically opposed. The first discourse focuses on the external (imperialist) determinants of the crisis and the latter on its internal (nation-state) determinants (Freeman, 2005). For example, from a nationalist perspective, Mandaza says that during the late 1990s post-nationalist forces in alliance with foreign elements were engaged in a subterranean 'social crisis strategy' that sought to make Zimbabwe ungovernable, and that the (supposedly radical) intellectual representatives of these forces sought to prioritise issues of governance and democracy 'at the expense of addressing the National Question'. The civic nationalism of these theorists (such as Raftopoulos) is portrayed as civil society warring against the state, and as seeking to undermine economic (re-distributive) nationalism rightly propagated (according to Mandaza) by a beleaguered nation-state under the onslaught of imperialism.

This dualist understanding is inconsistent with the theoretical points I raised earlier in relation to intermediary NGOs. The seemingly dichotomous moments - such as 'external' and 'internal', 'progressive' and 'regressive', and 'liberal-democratic' and 'nationalist' - are in actual fact internally-related contradictory moments, and are invariably (relational) co-determinants of both the process and product of 'fast track'. These contradictory trajectories adhered within and gave vitality to the land movement. Intermediary NGOs (as both victim and culprit) were 'caught in the crossfire' of these 'fast track' contradictory moments, notably the global-local contradiction.

\section{The Case of SOS Children's Villages ${ }^{3}$}

The world and work of intermediary NGOs need to be understood 'from within' through 'thick descriptions' of organisational practices; these practices cannot be read 
'from outside'. Conflicting pressures and demands that impinge upon (and within) the ambivalent social field of NGOs are 'handled' through organisational practices and 'strategies' that involve NGOs 'negotiating't their way through their tension-filled world, or even seeking to avoid 'handling' these tensions. These 'coping' practices, as suggested below, often have the effect of bringing a kind of stability to the world of NGOs that is otherwise not sutured. These points are illustrated in relation to the case study of SOS Children's Villages Zimbabwe.

\section{The Village Concept}

SOS Children's Villages International (called SOS-KDI for short) was formed in Austria in the immediate post-World War II period in response to the orphan crisis in Europe arising from the war. Over the past fifty years it has expanded around the globe in an effort to care for the needs of orphaned, abandoned and abused children. It operates in all countries in southern Africa. Its organisational structure in Zimbabwe is in many ways representative of its operations globally. SOS Zimbabwe is registered as a welfare organisation in Zimbabwe, and has been in the country since the1980s. It functions on the basis of the Village concept that has been the trademark of SOS-KDI since its inception. The Villages are located within urban communities but exist as selfenclosed, separate fenced-off entities. Normally, SOS owns the property on which the Villages are located, and this is said by SOS to express its commitment to remaining within any particular country no matter what political changes ensue. In Zimbabwe, there are three Villages: in Bindura, Harare and Bulawayo.

Each Village consists of about ten houses that are run by a Mother and assistant Mother, both of whom are full-time employees of SOS. Each house has about twelve children, of both sexes and of many ages. The children are wards of the state, and are referred to SOS by the Department of Welfare in the Ministry of Labour. SOS is thus legally responsible for the upbringing of the children. A male Director (until recently referred to as the Village Father) heads each Village. Each Director falls under the National Director at the National Coordinating Office (NCO) in Harare. All Village Directors and staff are Black.

SOS youth are meant to leave the SOS system in their early twenties after completing some form of post-secondary education or training. With start-up capital, they are expected to find employment or become self-employed. The academically-gifted SOS youth go to university, and others go to various types of technical colleges. However, those youth who fail to pass their ' $\mathrm{O}$ ' level examinations normally end up at what are called the SOS Vocational Training and Production Centres (VTPC) located on two farms fifteen kilometres from Bindura in the Shamva District of Mashonaland Central province.There are about fifty youths at the VTPC being trained in agriculture and engineering. 
Vocational Training and Production Centres

There are three NGO projects (called facilities) at the two farms: SOS Agricultural Training Scheme, SOS Maizelands Farm and SOS Engineering. Each facility has a Manager and an Administrator.

SOS Maizelands farm is a commercially run farm that was purchased in 1989 and it grows maize, soybean, wheat and bananas. It is expected by the NCO to turn over a profit (which it normally does) and generally it does not receive grants or subsidies from SOS Zimbabwe. Simultaneously, SOS Zimbabwe discourages it from seeking bank loans for the purchase of capital equipment as this goes contrary to proper NGO practice. In large measure, capital equipment has been purchased from profits. The farm itself was purchased for a mixture of reasons: to offer a commercial environment in which to train SOS youth in agriculture; to provide a temporary farmer settler scheme through which SOS youth would pass after graduating from the training scheme; and to provide staple food for the Villages. Effectively, the farm operates like any other private commercial farm in rural Zimbabwe. To any outside observer, and even to most of the junior farm employees, the formal NGO status of the farm has always been unclear. The Manager and Administrator are White and are husband and wife. The NCO now recognises that this working relationship goes contrary to good NGO practices of accountability but it has decided to let it continue. The farm Manager receives an annual commission based on farm revenue and profit.

The Manager and Administrator do not consider themselves bound to the SOS Conditions of Service in terms of the salary scale in force, and they pay their permanent staff (about 100 staff members) considerably less than the SOS scale. About half (or 40 per cent) of their staff have SOS contracts of employment but receive salaries amounting to 50 per cent less than the official SOS scale. The other permanent staff (guards and irrigation 'boys') are contracted directly to the farm, and are paid according to National Employment Council (Agriculture) rates, which amount to about US\$ 7 per month. The farm has always justified this type of arrangement on the grounds that paying their workers SOS rates (a minimum US\$ 60 per month) would create problems amongst their neighbouring farmers and would make the farm unproductive. SOS Zimbabwe has over the years accepted this rationale. Besides the permanent staff (nearly all male), the farm employs numerous weekly or seasonal contractors (nearly all female), many of whom reside on the farm as family members or relatives of permanent staff.

At SOS Glen Avilin Farm there are two vocational facilities for SOS youth: an agricultural training scheme (ATS) and an engineering training scheme (SOS Engineering). Both projects have a Manager and an Administrator, and all are White except for the Administrator at ATS. The long-standing Manager of SOS Engineering has always hired Whites as his Administrator because he believes that Blacks cannot be trusted. At times he has thought of employing his wife as the Administrator. He once 
informally raised this with the previous National Director (who retired in March 2005), but it was rejected on grounds of NGO transparency. The wife of the ATS Manager is the sister of the SOS Maizelands Manager, and there is considerable overlap (and indeed confusion) between professional and private lives at the two farms. This situation has also led to the blurring of distinctions between public NGO goods and private employee goods. For instance, the wife of the Maizelands Manager operates a farm store at Maizelands (and profits from it), and the wife of the ATS Manager regularly uses her husband's NGO-owned vehicle for private trips. At times, these practices border on the privatisation of public goods.

SOS Engineering has a large, well-equipped engineering workshop and it is supposed to run as a commercially viable venture. In the past it did significant volumes of work for White commercial farmers in the area, including the building of fixed assets such as farm sheds and repairs to moveable assets such as tractors and ploughs. More recently, though, it mainly relies on furniture orders from SOS-KDI for villages under construction throughout southern Africa. Over the past few years, because of reasons of political instability, SOS-KDI has put on hold any further Village construction in Zimbabwe itself. ATS has a more limited commercial side to its operations, primarily in the form of a grinding mill. The VTPC Managers have constantly questioned the status of their facilities with NCO. The ATS Manager has downplayed the (unprofitable) 'commercial' aspect of his facility so that $\mathrm{NCO}$ will continue to subsidise his vocational facility. The Engineering Manager failed to do this, and now he is under intense pressure from NCO to commercially 'break even' in terms of operational costs. All major building construction and the purchase of fixed assets at these facilities have involved grants from SOS-KDI.

Both facilities offer a three-year training programme, and each has two training officers. ATS has about thirty-five trainees and SOS Engineering has about fifteen trainees. Most of these youths come from the three Villages but included are also fifteen non-SOS ('scholarship') youths at the facilities drawn from other children's homes in Zimbabwe. On behalf of the Villages, SOS Zimbabwe pays the training facilities an amount of US $\$ 4,500$ per year per trainee. These facilities also receive the same amount for each 'scholarship' youth. The training fees are meant to cover trainee-related costs incurred by the facilities. The youth, who are all Black and mainly male, stay at hostels on SOS Glen Avilin Farm.

Once the agricultural trainees finish their three-year programme, they move to the Avilin Tenant Scheme that is located on Glen Avilin Farm. Initially, this was meant to be a transitional phase for the SOS youth venturing into agriculture on a full-time basis after leaving the SOS system. However, SOS has never had a strategy or plan for integrating their youth into surrounding agricultural communities in Shamva. At the Scheme, the tenants are given one or two hectares of land for cropping mainly maize, soybean and cotton. Over a three-year period as a tenant, they are expected to become financially self-sufficient although they also receive considerable support from 
Maizelands farm (for a cost) in the form of, amongst other things, tractor ploughing and agricultural inputs. In the end, they are expected to learn what it takes to be a farmer in the real (post-SOS) world. Recently though, and quite controversially, this temporary scheme has been turned into a permanent scheme.

SOS Maizelands farm and SOS Glen Avilin Farm are located in a prime agricultural area. Up until the year 2000, the Shamva District had about forty White commercial farmers. Only a few remain. As well, communal areas are within a thirty-minute drive from the SOS farms, and two 'old' resettlement farms (originally settled in the 1980s) border them.

\section{The Years Preceding 'Fast Track' Reform}

By the time accelerated (or 'fast track') reform emerged in the year 2000, SOS Zimbabwe had been operating in the Shamva district for over ten years. Yet, it had formed few if any structured linkages with the surrounding rural communities. Rather, these linkages were in large part ad hoc and personal. For instance, the White Managers and Administrators developed close personal ties with a number of White commercial farmers, and socialised with them outside working hours including at the Shamva Golf and Country Club. Indeed, prior to taking up his position at SOS Maizelands, the farm Manager was employed as a Manager by the White commercial farmer at nearby Nyamwanga Farm. These personal ties, and the positions adopted by the White SOS senior staff, came back to haunt SOS during the land reform programme.

Also, as noted earlier, SOS Engineering relied almost exclusively on White commercial farmers for productive work for its workshop. As well, Maizelands Farm drew female labour (for example, to grade maize seed) from the communal areas on a seasonal basis, and would daily truck them in on its lorry. There was rarely any contact with the 'old' settlers, except when their cattle strayed onto SOS property and feasted on its crops or when SOS farm workers illegally cut down trees in the resettlement areas. Lastly, many rural people in the surrounding area would travel to the ATS grinding mill to have their maize ground.

SOS Zimbabwe, and local management on the two farms, never saw any reason to meaningfully engage with the multi-faceted rural communities in Shamva in any conscious, direct or comprehensive manner. Such an approach never formed part of its organisational strategy, particularly given that its core business (and the centre of the organisation) was the Villages. SOS Zimbabwe, and in fact SOS-KDI, exist solely because of the Villages. The VTPC were designed to serve that child-centred purpose, and to offer some kind of future to their youth who (without ' $O$ ' levels) would likely have no opportunities to further their education. In this sense, the VTPC had an inwardlooking policy and approach, and never felt the need to embed themselves within the broader agrarian communities. 
'Fast Track' Land Reform

In September 1999, the opposition party the Movement for Democratic Change (MDC) was formed in Zimbabwe. Its leader, Morgan Tsvangarai, soon came to the provincial capital of Bindura to hold meetings and to drum up financial support. He held a meeting at Insingisi Farm, just outside Bindura, and White farmers thronged to hear him. Many farmers publicly declared their support for the MDC and even became local representatives for the party in the area. A referendum on a revised constitution, which included clauses on land acquisition and the executive presidency, was to take place in February 2000, and the MDC was campaigning for a 'No' vote. In the months preceding the referendum, farm workers in Shamva were loaded and squeezed onto the back of lorry trucks by commercial farmers and sent to MDC rallies in Bindura.

Most White commercial farms in the Shamva District were occupied soon after the holding of the referendum, although this was an uneven process. At times, specific occupations arose as a direct result of rallies held by the ruling party Zimbabwe African National Union-Patriotic Front (ZANU-PF) in the town of Shamva. Base camps, normally headed by war veterans, were set up on the occupied farms. Initially, there were constant negotiations between Black 'settlers', White farmers and the District War Veterans (make-shift) office in Shamva about the status of the 'settlers' on the farm. The 'settlers' made their presence felt on the farms by positioning their camps near the entrance of the homestead of the White farmer, by placing demands on the farmer for food and transport, and by at times forcefully preventing the farmer from ploughing or harvesting his fields. The occupied farms were later designated for resettlement, and some farmers were still leaving their properties as late as the year 2005. The remaining White farmers were able (for the time being) to secure their continued presence in the district.

The two farms owned by SOS were never occupied, and it appears that there was an unwritten directive from government that they not be occupied. The local ZANU-PF Member of Parliament, Nicholas Goche, intimated this to certain SOS staff in May 2000. Yet, this did not leave the SOS farms untouched by land reform. For instance, some supporters of ZANU-PF set up a base camp on Maizelands farm called the Border Gezi Base Camp, named after the (now deceased) ZANU-PF provincial governor for Mashonaland Central. On special occasions, this camp would issue (officially stamped) hand-written notes to SOS facility Managers, requesting contributions of various kinds (invariably transport and meat) for national celebrations such as Heroes Day. Demands of this kind also led Maizelands farm to contribute furniture (built by SOS Engineering) at no charge to a new secondary school in the immediate vicinity.

ZANU-PF activism on the SOS farms also increased dramatically during the years 2000 and 2001, and there were regular marches as well as meetings at which all farm workers were expected to attend. The SOS farms were rumoured to be sympathetic to the opposition. This was based on a claim by local ruling party activists that most of the 
ballots found in the boxes at the farm election points after the 2000 parliamentary and 2002 presidential elections were for the MDC. Numerous SOS workers were labelled as MDC supporters and at times were subjected to intimidation. Also, staff dismissed from work at the SOS farms on legitimate grounds (for example, theft) used 'Third Chimurenga' threats to intimidate their superiors. Thus, one dismissed employee at ATS organised a banner march on SOS Glen Avilin farm against the Administrator, and a former employee at SOS Engineering arranged for the new ZANU-PF-backed trade union federation (the Zimbabwe Federation of Trade Unions) to pay the National Director an impromptu visit at his offices in Harare.

Further, the Maizelands farm Manager allowed a prominent commercial farmer aligned to the MDC to stay at the SOS farm house when the latter was experiencing extremely difficult times at his farms. The Manager also permitted farm equipment from occupied farms (notably from Nyamwanga Farm) to be moved onto the SOS farms for safekeeping, as this was designed to prevent the equipment from being taken by the new farmers. In time, settlers from Nyamwanga Farm came to SOS Glen Avilin Farm (along with the police and a camera crew) and removed what they claimed was Nyamwanga (and thus their) property. In the process, and despite being shown documentation on SOS assets by the chief Security Officer at the SOS farms, they took assets (for example, irrigation pipes) that rightfully belonged to SOS.

As well, in 2001 the Government officially designated SOS Glen Avilin Farm for redistribution and resettlement purposes. In response to a local appeal by SOS, the Provincial Governor wrote to SOS and promised that the farm would not be resettled. The designation however was never repealed, although its period of enforcement has since lapsed. In December 2005, the Government listed SOS Maizelands Farm for land redistribution in terms of a recent amendment to the Constitution. The farm became state land and there is no basis for appeal. SOS has the option of asking for a ninetynine-year lease on the property. In the meantime, a prominent Black farmer in the area who is also a high-ranking military official assured the Maizelands farm Manager that SOS can continue as normal in its farm operations.

In the context of 'fast track' reform, the SOS farms continued to operate in an inwardlooking fashion. They have been largely reactive in their stance, responding to specific pressures and demands as they emanate. No attempt has been made to understand the radical agrarian change that has taken place in the district, and certainly no linkages whatsoever have been established with the newly resettled farmers. If anything, VTPC management bemoans the loss of the White commercial farmers as a source of both business and friendship.

\section{Organisational Dynamics}

SOS Zimbabwe has its national office in Harare. Its long-serving ex-National Director 
held the reigns of power from the year 1990 to March 2005. He is a former White commercial farmer. Although not a founder member of the NGO, over the years he without doubt stamped his authority and style of management on the organisation. This had direct implications for the VTPC in Shamva. All three White Managers at the VTPC are also long-serving staff members and over the years they developed close personal relations with the National Director to whom they reported.

In effect, the Director considered the VTPC as his sole responsibility and he did not allow any other member of the NCO to interfere in the VTPC operations. For instance, SOS Zimbabwe for many years has had the position of Financial Controller located at NCO. The financial affairs of the Villages have always fallen directly under the ambit of the Financial Controller, and Village Administrators have reported to the Controller. In the case of the VTPC, the Administrators have reported only to their facility Manager and they did not have any structured relationship with NCO. The current Financial Controller at NCO speaks about being 'sidelined' by the former National Director when it came to the VTPC. The (White) assistant National Director at the time (now the National Director since April 2005) was also marginalised and his area of responsibility was strictly the Black-run Villages. He at times described the VTPC Managers as 'the three musketeers'. Further, the position of Human Resources Officer at NCO was created in the mid-1990s and a Black woman was appointed. Despite her protests, she was denied access to the VTPC and subsequently resigned. The position was then abolished. For many years at NCO there has been an Education Coordinator responsible for, amongst other things, the (post-secondary school) academic and vocational needs of the SOS youth. Again, for reasons that remain unclear to the current occupant of this position, the VTPC have always fallen outside the parameters of this position.

This approach has led to the three NGO projects (or facilities) at the farms in Shamva being in large part privatised by the White Managers. These Managers have been given the leeway to conduct themselves and administer their projects in a manner that may not necessarily be in the best interests of the NGO as a whole, or that may at least be inconsistent with the vision of SOS. Intriguingly, the most junior of staff at the farms have noted this process of privatisation. In the eyes of many workshop staff at SOS Engineering, the Manager is seen to 'own the company'. Further, after discussing the issue privately for many years, the irrigation workers wrote to the Maizelands Manager in 2006 to ask if they are employed by SOS, Maizelands farm or by the Manager himself. This privatisation of public (NGO) goods arose and developed with the tacit support if not the active encouragement of the ex-National Director.

The Heads of Department at NCO, including the Financial Controller and the Education Coordinator, never directly challenged the Director on this score. Nor did the staff employed on the two Shamva farms openly question the facility Managers. In large part, staff felt powerlessness and feared risking their employment or the special benefits they received. The ATS Manager in particular has used his position to give perks to 
his key staff as part of some kind of patrimonial patron-client relationship. This has ensured their compliance to the system if not their loyalty to him. In this regard, many of the relationships at the VTPC have been personalised. This privatised and personalised system has meant that the VTPC operate as almost autonomous facilities (or fiefdoms) within SOS Zimbabwe.

Even more striking, there remains no clear indication that the VTPC in any way contribute to the overall vision and mission of SOS Zimbabwe. In this respect, there is no record of any form of either external or internal evaluation of the three farm facilities throughout their entire period of existence. This is a highly unusual state of affairs for an international NGO. It is also particularly problematic and perplexing given that the VTPC as projects within SOS-KDI are quite unique to Zimbabwe and thus constant monitoring and evaluation would presumably be critical to their overall forward direction. However, unlike the Villages, processes of evaluation have never been integrated into the organisational systems at the VTPC. Further, there is no monitoring and evaluation department at $\mathrm{NCO}$ to ensure that this gaping lacuna at the VTPC is rectified. In this context, it would appear that the VTPC have been deliberately shielded and protected from any outside investigation and interference. It is also highly unlikely that the VTPC Managers would welcome any monitoring and evaluation as this may uncover the many organisational dysfunctions that seem to exist at the VTPC.

\section{Organisational Dysfunctions}

The three farm facilities are NGO projects but, as noted above, they have been privatised and personalised. They are not consciously and intentionally run as NGO facilities, and there is no systematic attempt to develop a NGO organisational culture amongst the staff. The ex-National Director gave the three White Managers extraordinary perks (compared to the Black Village Directors) yet they do not have a basic understanding of NGO theory and practice. In fact, two of the Managers have no formal qualifications in any field and the third has a certificate in tobacco farming. On the other hand, the Village Director closest to the farms (in Bindura) has recently obtained a Masters degree in business administration. The White Managers have never sought to develop their managerial or NGO skills, and they normally avoid attending the managerial workshops organized by the Education Coordinator for all senior SOS Zimbabwe staff. In a sense, the ex-National Director granted them 'protected' or 'sheltered' employment, and they became increasingly entrenched in their positions. Despite the tremendous changes that took place in rural Zimbabwe since the year 2000, they stuck it out. This is not because of some deep altruistic commitment on their part to the vision of SOS Zimbabwe. Rather, it emanates from their likely inability to obtain comparable employment and benefits elsewhere in the country; they continue to live in their 'comfort zone' and, besides, they have nowhere else to go. 
This state of affairs has led to serious dysfunctions at the VTPC. I have already noted the failure on the part of NCO to properly evaluate the farm projects and the seeming disregard by the Managers for developing their managerial capacities. Beyond this, because the projects remain outside of the organisation's standardised financial systems, there is considerable financial irregularity and asset mismanagement at one of the two training projects. For instance, numerous personal items purchased with SOS funds are hidden in the 'trainee canteen' expense account. SOS assets are disposed of on an unauthorized basis, often to staff. As well, one training project manager has a major stake in the building company that did most of the construction on the farms.

Prior to his departure, the ex-National Director warned the VTPC Managers of impending changes likely to take place after he left. He highlighted in particular that the new National Director (at the time his assistant) might place the Financial Controller more directly over the farm facilities. One VTPC Manager raised deep concerns about this, and hoped that the Controller would merely implement an accounting function and not an audit function. In a similar vein, when a Human Resources Office was opened at the VTPC in late 2004, the VTPC Managers insisted that the job description of the Human Resources Officer specify that the Officer report not to NCO but directly to them. For over a year, the Officer refused to accept this clause.

Probably the most serious dysfunction concerns the major stakeholders of SOS, that is, the youth. The VTPC do not have to formally and systematically account to NCO for the expenditure of training fees they receive, nor for the conditions under which the youth live and train. The Managers at ATS and SOS Engineering wholly control the expenditure of the fees, without any input from the Training Officers. In so doing, the VTPC make a significant gross profit on their training departments (if training expenses are subtracted from training fees). Fees meant for the training department are used for other purposes in an uncontrolled fashion, such that the training facilities are severely under-resourced and compromised. For example, at the SOS farms there are more than ten computers but only one has been assigned to the training department. This is found in the office of a Training Officer, and the students have no access to a computer. There is also no library and recreational facilities are negligible. Recently, the long-standing canteen for trainees was converted into a number of offices, and for over a year the trainees were served their food from the back of a trailer drawn by a tractor down a dust road.

On a regular basis, the Training Officers have raised serious concerns about these issues to the ATS and SOS Engineering Managers, but no discernable changes have been forthcoming. The officers, despite their strategic position within the VTPC, feel largely excluded from the decision-making process within SOS and they would like to see the involvement of the national Education Coordinator in the farm facilities. The youth themselves, as the 'target group' of the NGO, are given few if any opportunities to formally raise complaints with VTPC management. In fact, they are in large part 
treated by management as 'objects' of development. A participatory mode of facilitating 'target group' involvement does not exist. But, through their (normally defunct) Student Representative Council, the youth have at times lodged a series of complaints and they regularly express their displeasure in everyday forms of resistance.

The Village Directors have also requested that they have an input into the management of the VTPC, considering that their youth are being trained there. They cite for example the case of the tenant settler scheme referred to above. In recent years, this scheme has been changed into a permanent scheme so as to become the kumusha (permanent rural home) of agricultural training graduates. The ex-National Director put this change into effect, and he spoke glowingly about it at his retirement gathering at the farm in March 2005. Some senior Black staff members at the farms refer to this as 'a white man's dream'. Indeed, the change goes contrary to the SOS policy that all SOS children be re-integrated into the broader community. From an original eight tenants in the late 1990s there are now about forty tenants occupying small houses. The land given to each tenant has decreased from three hectares to less than one hectare. For this and other reasons, the Bindura Village Director recently declared that his Village would no longer be sending any youth to the VTPC.

\section{Agrarian Change and Organisational Standstill}

At SOS Zimbabwe, there seems to be a serious discontinuity (if not gap) between the vision and mission of the organisation on the one hand, and organisational practice on the other. There is also considerable tension within organisational practices. SOS-KDI, and consequently SOS Zimbabwe, rests the legitimacy of its childcare interventions on its unique Village concept. This approach to childcare may have been path breaking and respectable decades ago, but in the context of current thinking (even Zimbabwean Government thinking), institutional care is increasingly criticised for not being good value for money. In other words, institutional care is financially draining and does not contribute to healthy personal development. Despite this, SOS continues to rest on its laurels so to speak by promoting the Village model, although at times (as noted earlier) in slightly modified form as in South Africa. The sustainability of SOS as a NGO rests fundamentally on upholding this model. However, despite its Tracking Footprints evaluation programme (which is meant to trace the career paths of ex-SOS youth), SOS has yet to systematically evaluate its childcare work in Zimbabwe.

Presently, there is no basis on which the organisation can stridently claim that it is contributing in any significant manner to sustainable livelihoods amongst its ex-youth as its most critical group of 'stakeholders'. In this regard, the practices of the organisation may be contributing more than anything else to the sustainability of the organisational form as a site of employment for its staff (as another body of 'stakeholders'). The organisation may be more staff-driven than beneficiary-driven. If 'sustainable livelihoods' 
is used as a crude proxy for sustainable development, then there appears to be a marked tension within SOS organisational processes between promoting sustainable development for the youth and promoting a sustainable organisation for the staff. This is particularly noticeable at the Villages. Despite (if not because of) the fact that the Village Directors and other senior Village staff are clearly committed to the vision of the organisation and they show a keen interest in their children and youth, the tension exists. They continue to sustain an organisational form that may in the end be counter-productive to the achievement of the mission of the NGO.

On the other hand, the tension at the VTPC is more between organisational vision and organisational practice than within practice itself. Unlike their counterparts at the Villages, the VTPC Managers are at no level driven by the SOS mission and vision. In this respect, there is a near chasm between a publicly declared NGO mission and privately held motivations and agendas. The vision and the practices seem to be pulling in opposing directions. This has arisen for reasons outlined above, namely, because of the relationship that developed over a number of years between the $\mathrm{NCO}$ and the VTPC, particularly between the ex-National Director and the VTPC Managers. This relationship, involving significant autonomy for the VTPC, was never conducive to the formation of solid NGO values and practices at the VTPC. What is problematic at the VTPC is not simply the product of their work but also the entire organisational process through which this product is to be generated. In sustaining the VTPC through 'fast track' land reform in the face of considerable adversity, the Managers were not seeking to maintain the interests of SOS as a value-driven NGO but rather the interests of an organisation per se and their positions of privilege within it.

The VTPC Managers have in large measure been insulated from the insecurities that arise from 'chasing donors'. In fact, the $\mathrm{NCO}$ has ensured that there is a regular flow of funds to sustain the projects, either in the form of grants or subsidies. In this way, NCO has effectively shielded the VTPC from the pressures of the 'global'. At the same time, the business and personal links that the Managers established with the surrounding agrarian communities have focused exclusively on White commercial farmers. These, of course, have been significantly disrupted because of land reform. Subsequent to this, the Managers have not sought to establish any organisational links with farmers in the new settlement schemes. This disposition to distance the organisation from the transforming 'local' was at one level consistent with the SOS youth-centred mission of the NGO and it also served, at least at first sight, to stabilise the world of the VTPC. After all, directly engaging with the 'fast track' crisis was fraught with dangers even with strategic forethought.

Simultaneously, though, the VTPC increasingly began to inhabit their secluded world, and almost became detached from the broader agrarian economy. They came to a standstill organisationally despite the winds of agrarian change. The current dysfunctions within the VTPC exist not so much because of 'mishandling' the heightened tensions 
(which mark 'fast track') between 'the global' and 'the local'. Rather, the dysfunctions arose because of the 'absence' of seeking to handle any tensions in a constructive fashion. By adopting a 'hands-off' posture vis-à-vis 'fast track', tensions and antagonisms built up within the NGO's rural programmes. Unknowingly, the external tensions became 'internalised' (or were 'transferred' into internal organisational processes) unmediated by any concerted attempt by the organisation to channel these tensions creatively. By failing to 'manage' these tensions, the NGO increasingly turned inward and moved in the direction of an immanent implosion.

\section{Organisational Dispositions and Stabilising Practices}

SOS Children's Villages Zimbabwe is not necessarily representative of all NGOs in the country in terms of its response to land reform. As noted earlier, there is considerable variation within the NGO 'sector'. In this last section of the paper, I seek to identify this variation by briefly considering two other NGOs that worked in the same province as SOS Children's Villages. But, I go on to suggest that there is a common tendency animating these (and ultimately other) NGOs; more specifically, contained in NGOs as organisational forms are dispositions and practices that serve to stabilise NGOs despite the turbulent world in which they find themselves.

\section{Farm Orphan Support Trust and Development Aid from People to People 5}

Farm Orphan Support Trust of Zimbabwe (FOST) is a local NGO also involved in the child 'sector' in Mashonaland Central province (and elsewhere). FOST works primarily with farm worker communities, and 'fast track' had a profound disabling impact on its practices. For instance, instead of promoting socio-economic development on the farms it increasingly focused on food relief and other welfare-style interventions (because of the crisis of rural livelihoods). FOST was thus forced to channel its activities in a direction that did not readily maximise the achievement of its original vision and mission. The lofty ideals for which FOST was originally established were sacrificed in part or put on hold. In the meantime, the NGO seeks to sustain itself as a viable organisational form while also in some way remaining relevant to the needs of its 'targeted' communities. Relief and emergency work does not equate to providing longterm foster care schemes or to promoting the rights of farm workers. But it does offer a basis for the continued existence of the NGO, and this is particularly so considering the significant donor backing that normally comes with such work. Indeed, it is likely through its relief interventions that FOST has been able to expand its operations over the past three or four years.

The social and organisational complexities on the ground in the 'new' settlement 
areas (including authority structures) are recognised by FOST as requiring careful and considered study before engaging with them. These complexities have severely inhibited FOST from seeking to embed its foster care programmes within the restructured agrarian landscapes. Vigorously seeking to penetrate these areas may have severely compromised the structural integrity of the organisation during the current turbulent period. As it were, staff members at FOST were already stretched to the limit, and any further organisational demands may have simply demoralised them. But, despite the argument by major bilateral donors (e.g. United States Agency for International Development - USAID) that engaging with the 'new' farm settlements entails complicity with the Zimbabwean government, FOST has sought to enter these settlements on non-agricultural (e.g. orphan support) grounds. Thus, in the face of accelerated reform, FOST has tried to 'balance' its development practice through 'sensitive negotiations' with both global donors and local power structures. As a result, it has been able to 'weather the storm', and to manoeuvre its way through a restructured and tension-filled agrarian landscape in a manner that has not seriously jeopardised its organisational integrity and sustainability. Unlike SOS, FOST has directly and creatively 'handled' the tensions between global and local forces.

Development Aid from People to People (DAPP) in Zimbabwe is an indigenous NGO that is linked to HUMANA People to People internationally. It operates primarily in the Shamva District of Mashonaland Central province. Prior to 'fast track', it owned five commercial farms in the district. In the mid-1990s it initiated a Communal to Commercial (CC) Farmer Programme in which communal peasant farmers would be taught modern commercial farming methods. The CC programme was done with the full acknowledgement and support of the Ministry of Agriculture. It involved selecting a limited number of seemingly capable communal farmers and allocating them land on DAPP commercial farms. These farmers would live, work and be trained at these farms over a three-year period and would then qualify as (government-recognised) 'master farmers', after which they could apply for resettlement as part of the government programme or jointly purchase a commercial farm with DAPP assistance. The CC programme started at one of the farms in 1997 and the first intake of farmer-students began to graduate just prior to the emergence of the land movement in 2000.

The government designated (for redistribution) three of the five farms owned by DAPP, including one large 600 hectare farm that was purchased by DAPP in 1999 and at which the NGO had major plans to expand the CC programme. It is left with two smaller farms, one that houses HUMANA's international offices and one that offers internal training for HUMANA employees who work throughout southern Africa. HUMANA senior staff members are all White expatriates, and they have a pronounced altruistic drive that emanates from many decades of involvement in NGO work. Their development ideas and methods have a paternalistic thrust, as encapsulated in the notion that peasants need to be 'made modern'. Yet, in the light of land reform, they 
argue that Zimbabweans have the right to decide their own development destiny. As a result, and unlike most other development NGOs in Zimbabwe, they have not distanced themselves from 'fast track'. Soon after their farms were taken, they approached the Ministry of Lands and asked what kind of NGO work would be appropriate under the altered political and rural landscape. It was suggested to them that the $\mathrm{CC}$ programme could now be implemented 'on site', that is, in the 'new' resettlement areas. For the past few years, and in conjunction with government agricultural extension officers, they have been doing this on a significant scale in the Shamva District. They are trying to instil within 'new' small-scale farmers the 'modern' commercial mode of agricultural work and life.

\section{Dancing Around Many Spots}

At a civil society consultative workshop held by the Commonwealth Foundation in Harare in the year 2002, one participant depicted NGOs in Zimbabwe as 'dancing around the same spot'(NANGO,2002:13). Potentially, this portrait has a triple meaning. First of all, it may mean that the spot never changes and NGOs have all their wheels in the rut. In this regard, it implies that NGOs are not learning organisations, that they function without strategic forethought and that they are inherently conservative (if not politically then organisationally). Secondly, the portrait may mean that NGOs prefer (or are constrained) to remain on an unchanging spot while all spots around them are constantly shifting. Third of all, the phrase might mean that all NGOs dance to the same tune, although at times the tune (or spot) might change. In other words, NGOs have some sort of herding instinct or have the same shepherd, and hence they are invariably found pursuing common policies and practices.

All three shades of meaning likely have some element of truth. But none, on its own, serves as an accurate barometer of the work of NGOs in Zimbabwe during 'fast track'. Combined, the three meanings crudely 'fix' NGOs as static organisational forms devoid of all fluidity and diversity. NGOs in Zimbabwe are complex social phenomena that are constantly in motion and they are marked by considerable diversity. As a 'sector', both development and advocacy NGOs have not been particularly proactive in 'handling' fast track' land reform (Helliker, 2007). But specific NGOs have shown significant adaptive capacity. Further, responses to land reform have been incredibly diverse, ranging from the 'hands off' approach of SOS to the 'testing the water' position of FOST to the 'gung ho' approach of DAPP.

To pin an all-embracing (catch-all) label (of any kind) on NGOs is highly problematic not only empirically but also theoretically. For instance, such labels fail to come to grips with the ambivalences and contradictions that invariably mark the world and work of NGOs. Generally speaking, NGOs seek to 'manage' and 'negotiate' their social world through a multitude of organisational strategies that often pull in opposing directions. The organisational practices of NGOs are not necessarily one-dimensional 
or unidirectional, and they are subject to significant levels of ambiguity, fluidity and even confusion. Therefore, if NGOs are dancing, then they are more than likely 'dancing on many spots', and on uneven, unstable and shifting ground.

NGOs often 'manage' the ambivalences in their world by avoiding or simplifying complexities through specific organisational practices. In doing so, they try to stabilise their world. The outcome of this 'managed' process is open to considerable historical variation. In the case of contemporary Zimbabwe, it has resulted in NGOs - as a general trajectory - creating 'distance' between themselves and land reform, both before and during 'fast track' reform. Prior to the year 2000, the distance was particularly telling at the level of advocacy. NGOs refrained from concerted lobbying despite a reasonably conducive environment for doing so. On the other hand, under 'fast track', there is a marked distance at the operational level, as development NGOs seem disengaged from the 'new' resettlement areas. Politics and ideology, and the conflicts they inspire, clearly contribute to the sheer complexity of engaging in land reform either at the policy or implementation level, and hence this distance exists. However, in the following comments, I privilege the organisational dispositions that drive NGOs.

\section{Reproducing NGOs as an Organisational Form}

As noted, most intermediary NGOs in Zimbabwe, including advocacy and development NGOs, have in many ways distanced themselves from 'fast track' land reform and the newly resettled areas. But two points require clarification.

First of all, it is highly problematic to assume that acts of immobilisation or distancing represent signs of NGO incapacities and weaknesses. The work of SOS and FOST, for example, point to organisational actions (and inactions) which seemingly indicate blatant NGO failure, such as the retreat from long-term development initiatives on commercial farms and the inability to become embedded within changing agrarian communities. Yet, such a conclusion may entail confusing organisational problems with organisational solutions. In other words, these organisational practices turned out to be (at least in the case of FOST) the NGO way or solution to weathering the turbulence of the contentious land reform in Zimbabwe, and to remaining as viable organisational forms under politically volatile conditions.

Secondly, it is tempting to interpret distancing in terms of the (middle) class bias of intermediary NGOs, or at least in terms of their (apparently conservative) political and ideological dispositions. Again however this in large part involves a conceptual confusion and, in this case, between political dispositions and organisational dispositions. Distancing acts cannot be reduced to political-cum-ideological dispositions on the part of NGOs; nor does the overt pressure placed upon these NGOs by global donors provide a sufficient explanation. Instead, it is critical to go beyond politics and to enter the 'inside world' of these NGOs. This entails identifying the 'internal' dispositions and 
interests that shape NGO organisational practices.

In this respect, NGOs are disposed to minimise the complexities of their world through organisational practices, albeit unintentionally. Land reform is a particularly twisted and complicated terrain for intermediary NGOs, in relation to both advocacy and development work. The existence of organisational dispositions that stabilise their world indicates that NGOs are not invariably against radical land reform or that, if they are, this stance is not to be interpreted in purely political terms. If NGOs involved in land reform do operate contrary to local empowering initiatives and thereby support global trajectories, they do so primarily because of their own organisational interests.

More generally, it is critical to understand why intermediary NGOs do what they do in a manner which is sensitive to the 'inside story'. As raised earlier, intermediary NGOs as a rule do not work on behalf of global forces or at their behest, although there may be some empirical truth to suggestions that they do. For instance, even a cursory reading of recent documents produced by USAID leads to the instrumentalist conclusion that American foreign policy seeks to consciously and deliberately slot NGOs into its global hegemonic designs (USAID, 2002). It may also be asserted, with some justification, that 'existing power relations' within the development industry 'distort and divert the bestintentioned [value] approach' of NGOs (Rowlands, 2003:6) and therefore NGOs - by some structural necessity - are subservient to global relations of domination.

However, in reproducing global forms of domination, NGOs do not directly capitulate to powerful interests or structural demands in some unmediated fashion. Rather, the historically forged and contingent interests of NGOs tend to be consistent with the contemporary interests of capitalist globalisation, and hence NGO interests could be said to 'complement' these global interests. However, NGO interests are not abstract structural interests but arise as NGOs seek to stabilise their inherently fluid and ambiguous world. These interests do not entail brute material rationalisations, but are subjective interests heavily laden with meaning.

\section{Conclusion}

Intermediary NGOs negotiate their way in and through their social world, and this involves ambivalent, uncertain and (often) frustrating relations with donors, rural communities and the state. NGOs, although without conscious intent, resolve the tensions and ambivalences in their world by 'fixing' or 'stabilising' their own organisations even if this goes contrary to sustainable development (Brinkerhoff and Goldsmith, 1992). This explains in part why the development industry continues unabated, as a recursively self-reproducing set of global relations, although there is only limited if any sustainable development taking place because of it.

NGOs structure, stabilise and enact closure on their world; in other words, as an organisational disposition, NGO suture their world and bring a simple coherence 
and logic to it. This may entail all sorts of simplifying assumptions and practices that undermine sustainable development and serve only to reproduce the status quo, including homogenising the needs of differentiated rural communities or restricting their participation (and empowerment) to the bare minimum (Crewe and Harrison, 1998:190-194).

In undertaking their development and democracy work, NGOs tend to prioritise 'the global' and problematise 'the local'. But, in the end, they over-privilege their own organisational stability and sustainability. Although they work within the confines of global forms of domination, NGOs re-centre the world of development in a way that gives primacy to their organisations. As Power, Maury and Maury (2003:87) put it, NGOs 'set up internal but largely unrecognised barriers to their own values-driven goals' so that the latter - along with needs of marginalised rural communities - are often, unconsciously, sacrificed on the altar of NGO self-preservation.

This is how NGOs walk the tightrope of tension between the universal and the particular, and between the global and the local. They do not seek to reproduce global domination, nor are they manipulated to do so, but in pursuing order and stability along the social interfaces of their world, they by implication preserve the existing relations of domination. This, though, is not an inevitable consequence of the development system. Rather, it is the product of the existing balance of forces within the development industry.

\section{Endnotes}

1 Chimurenga is a Shona term meaning 'war of liberation'. The First Chimurenga refers to the struggles against land dispossession by indigenous people in the early years of colonialism, and the Second Chimurenga relates to the guerrilla war leading to independence in the year 1980.

2 The 'Scrutator' in The Zimbabwe Mirror, $28^{\text {th }}$ April to $4^{\text {th }}$ May 2000. Ibbo Mandaza is widely known to be writer of this weekly column.

3 The discussion on SOS Children's Villages is based on my employment with the organisation from 1999 to 2006.

4 I use the term 'strategies' loosely and the term 'negotiating' broadly. The term strategy (if understood narrowly) would over-valorise the existence and significance of coherent forethought and planning in NGO work; likewise, a narrow definition of negotiating would incorrectly imply that NGOs are invariably involved in formal, direct and specific negotiations. My use of the terms strategy and negotiation are simply designed to highlight that NGOs seek through a range of practices (sometimes intentionally, sometimes not) to cope with the ambivalences and tensions that mark their world.

5 Information for this sub-section is taken from Helliker (2007). 


\section{References}

Bernstein H. 2005. 'Rural land and land conflicts in sub-Saharan Africa' in Moyo S and P Yeros (eds). 2005. Reclaiming the Land: The Resurgence of Rural Movements in Africa, Asia and Latin America. London: ZED Books

Bond P and M Manyanya.2003.Zimbabwe's Plunge: Exhausted Nationalism, Neoliberalism and the Search for Social Justice. Harare: Weaver Press.

Brinkerhoff D and A Goldsmith. 1992. 'Promoting the sustainability of development institutions: a framework for strategy'. World Development. 20(3).

Carroll T. 1992. Intermediary NGOs: The Supporting Link in Grassroots Development. West Hartford: Kumarian Press.

Crewe E and E Harrison. 1998. Whose Development?: An Ethnography of Aid. London: Zed Books.

Eade D. 2003. 'Preface' in Eade D (ed). 2003. Development Methods and Approaches: Critical Reflections. Oxford: Oxfam GB.

Edwards M and D Hulme. 1996. 'Beyond the magic bullet? Lessons and conclusions' in Edwards M and D Hulme (eds). 1996. Beyond the Magic Bullet: NGO Performance and Accountability in the Post-Cold War World. Connecticut: Kumarian Press.

Freeman L. 2005. 'Contradictory constructions of the crisis in Zimbabwe'. Carleton University. www.arts.yorku.ca/african liberation/conferencepapers

Ghimire K (ed). 2001. Whose Land?: Civil Society Perspectives on Land Reform and Rural Poverty Reduction. Rome: Popular Coalition to Eradicate Hunger and Poverty/UNRISD. www.landcoalition.org/docs

Hammar A and B Raftopoulos. 2003. 'Zimbabwe's unfinished business: rethinking land, state and nation' in Hammar A, Raftopoulos B and S Jensen (eds). 2003. Zimbabwe's Unfinished Business: Rethinking Land, State and Nation in the Context of Crisis. Harare: Weaver Press.

Hammar A, Raftopoulos B and S Jensen (eds). 2003. Zimbabwe's Unfinished Business: Rethinking Land, State and Nation in the Context of Crisis. Harare: Weaver Press.

Helliker K. 2005. 'Review Essay of Moyo S and Yeros P (eds). 2005. Reclaiming the Land: The Resurgence of Rural Movements in Africa, Asia and Latin America. Zed Books. London. 2005'. African Sociological Review. 9(2).

Helliker, K. 2007. 'A Sociological Analysis of Intermediary Non-Governmental Organisations and Land Reform in Contemporary Zimbabwe'. Unpublished $\mathrm{PhD}$ thesis, Department of Sociology, Rhodes University.

Kanji N, Braga C and W Mitullah. 2002. Promoting Land Rights in Africa: How Do NGOs Make a Difference? London: IIED. 
Manji F and C O'Coill. 2002. 'The missionary position: NGOs and development in Africa'. International Affairs. 78(3).

Monga C. 1996. The Anthropology of Anger: Civil Society and Democracy in Africa. Boulder: Rienner Publishers.

Moore D.2003.'Zimbabwe's triple crisis: primitive accumulation, nation-state formation and democratization in the age of neo-liberal globalisation'. African Studies Quarterly.7(2 \& 3).

Moore D. 2004. 'Marxism and Marxist intellectuals in schizophrenic Zimbabwe: how many rights for Zimbabwe's Left? A comment'. Historical Materialism. 12(4).

Morris-Suzuki T. 2000. 'For and against NGOs: the politics of the lived world'. New Left Review. 2.

Moyo S. 2001. 'The land occupation movement and democratisation in Zimbabwe: contradictions of neoliberalism'. Millennium: Journal of International Studies. $30(2)$.

Moyo S, Helliker K and T Murisa (eds). 2008. Contested Terrain: Land Reform and Civil Society in Contemporary Zimbabwe. Pietermaritzburg: SS Publishing.

Moyo S and P Yeros. 2005. 'Land occupations and land reform in Zimbabwe: towards the national democratic revolution' in Moyo S and P Yeros (eds). 2005. Reclaiming the Land: The Resurgence of Rural Movements in Africa, Asia and Latin America. London: ZED Books.

NANGO. 2002. 'Report on the Proceedings of the Commonwealth Foundation and Zimbabwe Civil Society Consultative Workshop, 27 May 2002'. Harare: National Association of Non-Governmental Organisations and Commonwealth Foundation.

Power G, Maury M and S Maury. 2003. 'Operationalising bottom-up learning in international NGOs: barriers and alternatives' in Eade D (ed). 2003. Development Methods and Approaches: Critical Reflections. Oxford: Oxfam GB.

Raftopoulos B. 2005. 'The Zimbabwean crisis and the challenges for the Left'. Public Lecture Delivered at the University of Kwa-Zulu Natal. 23 June 2005

Raftopoulos B and I Phimister. 2004. 'Zimbabwe now: the political economy of crisis and coercion'. Historical Materialism. 12(4).

Ranger T. 2004. 'Nationalist historiography, patriotic history and the history of the nation: the struggle over the past in Zimbabwe'. Journal of Southern African Studies. 30(2).

Rowlands J. 2003. 'Beyond the comfort zone: some issues, questions, and challenges in thinking about development approaches and methods' in Eade D (ed). 2003. Development Methods and Approaches: Critical Reflections. Oxford: Oxfam GB.

Sachikonye L. 2002. 'Whither Zimbabwe? Crisis and democratisation'. Review of African Political Economy. 29(91).

Uphoff N. 1996. 'Why NGOs are not a third sector' in Edwards M and D Hulme (eds). 
1996. Beyond the Magic Bullet: NGO Performance and Accountability in the PostCold War World. Connecticut: Kumarian Press.

USAID. 2002. Foreign Aid in the National Interest. Washington.

Vakil A. 1997. 'Confronting the classification problem: toward a taxonomy of NGOs'. World Development. 25(12).

Yeros P. 2002. 'Zimbabwe and the dilemmas of the Left'. Historical Materialism. 10(2). 